\title{
Adsorption Removal of Phenol and Cresol by Surface-Modified Activated Carbon for Treatment of Effluent from Hospitals
}

\author{
Takeo Nakamura, Tamotsu Miyoshi, Seiki Tanada \\ and Keito Boki \\ Department of Public Health, School of Medicine, Tokushima University, Tokushima
}

\section{INTRODUCTION}

The Water Pollution Control Law was submitted to the environmental protection session of the Diet in 1970. The objectives of the law were to correct the pattern of administration in which regulation followed, but did not abate or prevent pollution, to strengthen measures for enforcing effluent standards, to transfer enforcement powers to local authorities, and to create a system for monitoring and evaluating public waters ${ }^{1}$. Under this law, water quality has been improving in recent years. Although effluents from manufacturing factories have been regulated, there are many other facilities that drain effluents containing pollutants. In 1979 a new amendment was proposed and passed. The application of this law has been extended to control the effluent from hospitals ${ }^{1,2)}$. A primary characteristic of the effluent from hospitals is that it contains a large amount of disinfectants.

Little work on the treatment of the effluent from hospitals has been done so $f^{2 r^{3 \sim 6}}$. In general, effluents containing organic pollutants have been treated by the activated sludge method. Treatment by this method, which uses bacteria, has some drawbacks. The treatment rate is slow, it needs a large site area, and it produces a large amount of surplus sludge. However, it is effective when adsorbents such as activated carbon are used for waste water treatment, particularly during advanced treatments ${ }^{7}$. In the case of the use activated carbon for gas or liquid phase adsorption, considerable significance is attached to the physical properties of the adsorbent. In recent years, however, it has been found that the number of chemically active sites on activated carbon is significant ${ }^{8)}$.

For this work we prepared surface-modified activated carbons and we will discuss the treatment of effluent from hospitals from the standpoints of amount adsorbed and adsorption rate.

\section{MATERIALS AND METHODS}

\section{Materials}

Phenol was of extra-pure reagent grade (Wako Pure Chemical Industries Co., Ltd.), more than 99\% pure. Saponated cresol solution was of the Japanese pharmacopoeia grade (Yamazen Chemicals Co., Ltd.) and its concentration was indicated as $50 \%$.

Raw activated carbon (AC) was obtained from Wako Pure Chemical Industries Co.,Ltd. and its particle mesh size ranged from 4 to 7 .

Preparation of N-containing activated carbon (NC-AC) was carried out as follows: Twenty grams of AC was impregnated with $50 \mathrm{ml}$ of $20 \%$ L-lysine monohydrochloride solution for $24 \mathrm{hrs}$ at room temperature, and then collected by filtration with suction. AC impregnated with L-lysine was placed in a covered crucible and heated continuously up to a temperature of $850^{\circ} \mathrm{C}$ in an electric furnace. It was then kept for $5 \mathrm{~min}$ at $850^{\circ} \mathrm{C}$ and cooled to room temperature under a stream of nitrogen gas.

Preparation of plasma-treated activated carbon (PT-AC) was done as follows: Twenty grams of AC was placed in a reaction vessel, followed by degassing down to $0.5 \mathrm{mmHg}$. Then oxygen gas was flowed into the vessel while the evacuated $\mathrm{AC}$ was being treated with an oxygen plasma. The pressure during the treatment was kept at $5 \mathrm{mmHg}$. The high-frequency power and the treatment time were $20 \mathrm{~W}$ and 
5 hrs, respectively.

The physicochemical properties of these preparations are shown in Table 1.

2 Methods

\subsection{Determination of equilibrium isotherms}

Adsorption equilibrium isotherms were obtained for the phenol-water/adsorbent system. Five hundred milligrams of activated carbon was shaken with $50 \mathrm{~m} l$ of adsorbate solution of ca. 500 to $10000 \mathrm{ppm}$ at a constant temperature of $25^{\circ} \mathrm{C}$. It took 4 days to attain equilibrium adsorption. After equilibration, the phenol and cresol concentrations in the supernatant solutions were measured using a spectrophotometer (Hitachi model 101), and determined to be 270 and $275 \mathrm{~nm}$, respectively.

\subsection{Measurement of adsorption rate}

The adsorption rate was measured according to the method of Urano and Nakai ${ }^{9}$. Four grams of activated carbon were placed in a flask containing distilled water, and the suspension was boiled for $1 \mathrm{hr}$ to displace the air in the pores of the activated carbon with water. The activated carbon impregnated with water was placed in $800 \mathrm{~m} l$ of a stirred adsorbate solution (ca. $100 \mathrm{ppm}$ ). A solution of $20 \mathrm{~m} l$ was sucked up from the suspension by means of a $20-\mathrm{m} l$ pipette at regular intervals of elapsed time, and immediately an adsorbate solution with a concentration of ca. $1000 \mathrm{ppm}$ and distilled water were added into the suspension until its concentration and its volume became $100 \mathrm{ppm}$ and $800 \mathrm{~m} l$, respectively. The amount of adsorbate adsorbed was determined by the isotherm method.

\subsection{Pore size distribution and specific surface area}

The pore size distribution of the activated carbon was measured by a previously described method ${ }^{10)}$. The specific surface area of the activated carbon was measured by means of the BET method ${ }^{10}$.

2.4 Quantity of surface carboxyl group

The quantity of the surface carboxyl group on the activated carbon was measured by the titration method described by Boehm, et al. ${ }^{11}$. One gram of activated carbon and $50 \mathrm{~m} l$ of $0.05 \mathrm{~N} \mathrm{NaHCO}_{3}$ were placed in an Erlenmeyer flask. After shaking for $24 \mathrm{hrs}$ at $25^{\circ} \mathrm{C}$, it was allowed to stand for $96 \mathrm{hrs}$. After filtration, $20 \mathrm{~m} l$ of filtrate was titrated with $0.05 \mathrm{~N} \mathrm{HCl}$. At the same time, a blank test was also done.

\section{RESULTS AND DISCUSSION}

1 Equilibrium adsorption of phenol and cresol onto activated carbon

Adsorption isotherms of phenol and cresol onto activated carbon at $25^{\circ} \mathrm{C}$ are shown in Figure 1. The logarithm of the amount adsorbed is plotted linearly against the logarithm of the equilibrium concentration. The linear relationship indicates that both the adsorption of phenol and cresol are of the Freundlich type. The Freundlich equation can be expressed in the following form:

$$
\log \mathrm{V}=1 / \mathrm{n} \log \mathrm{C}+\log \mathrm{k}
$$

where $\mathrm{V}$ is the amount adsorbed, $\mathrm{C}$ is the equilibrium concentration, and $\mathrm{n}$ and $\mathrm{k}$ are constants. In general, the Freundlich equation can be applied to the adsorption of organic compounds onto activated carbon in a liquid state. The greater the $\mathrm{k}$ value, the more adsorbate is adsorbed. It is easy for adsorbate to be adsorbed when the $1 / \mathrm{n}$ value is in the range of 0.1 to $0.5^{12)}$.

Table 2 shows the Freundlich constants and amount adsorbed at each equilibrium concentration. The amount adsorbed was determined by isotherm experiments. The $\mathrm{k}$ value of phenol adsorbed onto the surface-modified activated carbon was smaller than that onto AC. However, the $\mathrm{k}$ value of cresol onto NC-AC was at least 1.5 times greater than that onto AC. All $1 / \mathrm{n}$ values of phenol and cresol onto activated carbon were in the range of 0.106 to 0.340 . The amount of phenol adsorbed onto PT-AC was smaller than that onto $\mathrm{AC}$ and NC-AC for each equilibrium concentration. For cresol adsorption onto PT-AC, the amount adsorbed was also small, being in the range of less than approximately $600 \mathrm{ppm}$, as shown in Figure 1. Both phenol and cresol were highly adsorbed onto NC-AC. 


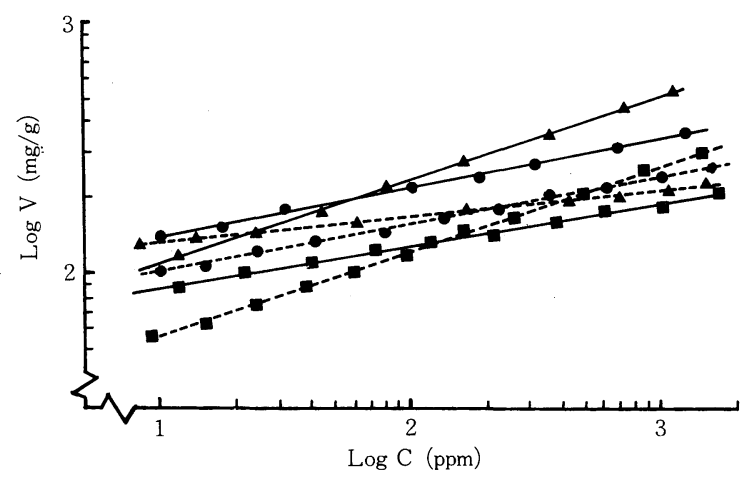

Fig. 1 Adsorption isotherms of phenol and cresol onto activated carbon at $25^{\circ} \mathrm{C}$. $\mathrm{V}$ : equilibrium amount adsorbed; $\mathrm{C}$ : equilibrium concentration; —: phenol ; …- : cresol ; : $\mathrm{AC} ; \boldsymbol{\Delta}: \mathrm{NC}-\mathrm{AC}$; 口 : PT-AC.
Table 2 Freundlich constant and equilibrium amount adsorbed.

(Phenol)

\begin{tabular}{rcccccc}
\hline \multirow{2}{*}{$\begin{array}{l}\text { Adsorb- } \\
\text { ent }\end{array}$} & \multicolumn{2}{c}{ Freundlich constant } & & \multicolumn{3}{c}{ Amount adsorbed $(\mathrm{mg} / \mathrm{g})$} \\
\cline { 2 - 3 } \cline { 6 - 7 } & $\mathrm{k}(\mathrm{mg} / \mathrm{g})$ & $1 / \mathrm{n}$ & & $10 \mathrm{ppm}$ & $100 \mathrm{ppm}$ & $1000 \mathrm{ppm}$ \\
\hline AC & 96.0 & 0.191 & & 136.0 & 211.0 & 328.0 \\
NC-AC & 58.4 & 0.328 & & 107.0 & 214.0 & 485.0 \\
PT-AC & 63.3 & 0.165 & & 85.0 & 121.0 & 182.0 \\
\hline
\end{tabular}

(Cresol)

\begin{tabular}{rrrrrrrr}
\hline \multirow{2}{*}{$\begin{array}{l}\text { Adsorb- } \\
\text { ent }\end{array}$} & \multicolumn{2}{l}{ Freundlich constant } & & \multicolumn{3}{c}{ Amount adsorbed $(\mathrm{mg} / \mathrm{g})$} \\
\cline { 2 - 3 } \cline { 6 - 7 } & $\mathrm{k}(\mathrm{mg} / \mathrm{g})$ & $1 / \mathrm{n}$ & & $10 \mathrm{ppm}$ & $100 \mathrm{ppm}$ & $1000 \mathrm{ppm}$ \\
\hline AC & 79.0 & 0.188 & & 105.0 & 162.0 & 250.0 \\
NC-AC & 115.0 & 0.106 & & 137.0 & 173.0 & 223.0 \\
PT.AC & 33.5 & 0.340 & & 57.5 & 126.0 & 275.0 \\
\hline
\end{tabular}

The adsorption capacity of activated carbon is dominated by pore structure and surface chemical factors. The surface areas and pore volumes of the activated carbons were successively higher in the order AC $>$ PT-AC $>$ NC-AC. Therefore, it was expected that the amount adsorbed onto AC would be greater than that onto NC-AC. However, our results indicated that the amount adsorbed onto AC was less than that onto NC-AC. Kawazoe, et al. ${ }^{13)}$ reported that sodium dodecylbenzen sulfonate was adsorbed consecutively from the smallest pores to the largest pores of activated carbon. Figure 2 shows the pore size distribution curves of activated carbon. Micropore $(\mathrm{r}<15-16 \AA)$ volume, which governs the adsorption capacity, is greater in AC than in NC-AC. From these results it was found that the amount of phenol and cresol adsorbed onto activated carbon are not solely determined by the pore structure of activated carbon.

Concerning the surface charge of meso-carbon microbeads, it has been reported that the zeta potential of untreated carbon is positive, while that of carbon treated with oxygen plasma becomes negative ${ }^{14)}$. On bulk meso-carbon, it is reported that the zeta potential of an untreated sample is negative. After the oxygen plasma treatment, the zeta potential of the sample becomes much more negative. In contrast, the zeta potential of samples treated with nitrogen and ammonia plasma becomes positive. The nitrogen content of a sample increases by irradiation with nitrogen and ammonia plasma ${ }^{15)}$. It appears that the zeta potential of PT-AC is negative because the concentration of the carboxyl group is as much as 2.4 times greater than that of $\mathrm{AC}$, whereas the zeta potential of NC-AC is positive because the nitrogen content is as much as 4.8 times greater than that of AC. Therefore, we assume that the difference in the amounts of phenol and cresol adsorbed is based on the interaction between the surface charge of activated carbon and the phenolic anion.

2 Adsorption rate of phenol and cresol onto activated carbon

For the case of liquid phase adsorption, intraparticle diffusivity is of major importance since it is the rate-determining step in the adsorption process. $\mathrm{Keii}^{16)}$ reported the following equation for calculating the intraparticle diffusivity $\left(\mathrm{Di}^{\prime}\right)$. It refers to the concentration of adsorbate in a solid adsorbent for liquid phase adsorption under nonlinear equilibrium :

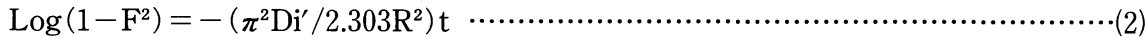

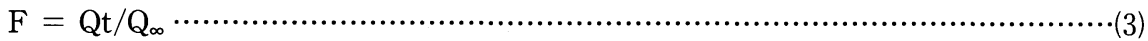

where $\mathrm{F}$ is the adsorption ratio, $\mathrm{R}$ is the particle radius of adsorbent, $\mathrm{t}$ is the adsorption time, $\mathrm{Qt}$ is the amount of adsorbate adsorbed in the solid adsorbent at an elapsed time, and $\mathrm{Q}_{\infty}$ is the equilibrium amount 


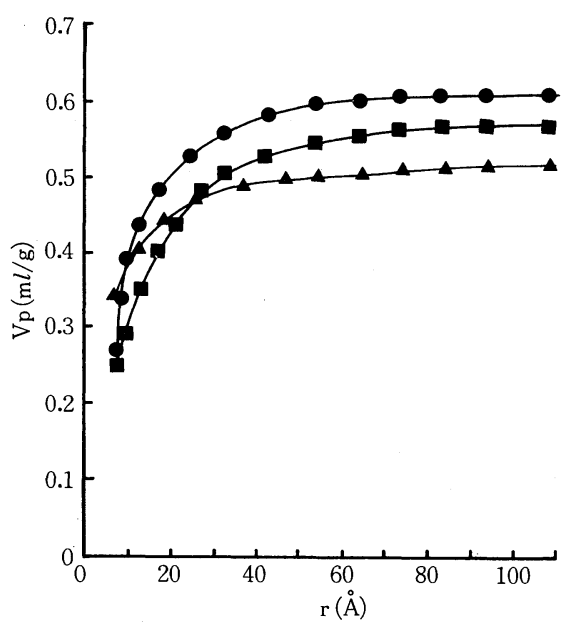

Fig. 2 Pore size distribution curves of activated carbon. $\mathrm{V}_{\mathrm{p}}$ : integral pore volume $\mathrm{r}$ : pore radius ; : $\mathrm{AC} ; \boldsymbol{\Delta}: \mathrm{NC}-\mathrm{AC} ; \boldsymbol{\square}: \mathrm{PT}-\mathrm{AC}$.

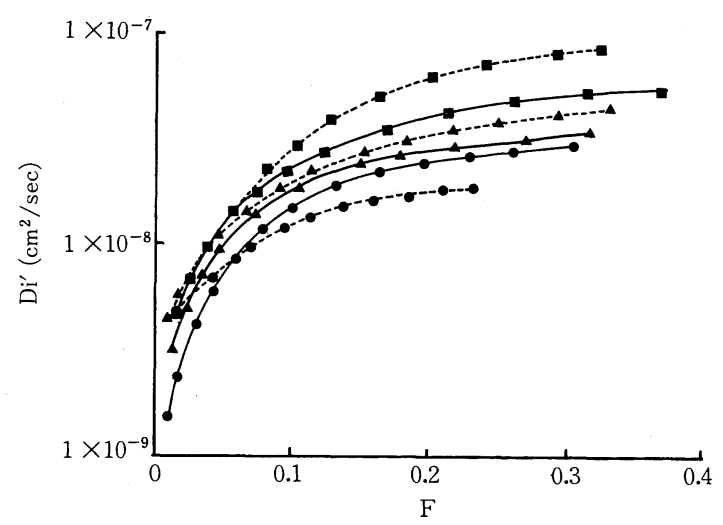

Fig. 3 Change in intraparticle diffusivity with adsorption ratios of phenol and cresol. $\mathrm{Di}^{\prime}$ : intraparticle diffusivity ; $\mathrm{F}$ : adsorption ratio ; - : phenol ; -...- cresol ; : AC ; $\mathbf{A}: \mathrm{NC}-\mathrm{AC}$; PT-AC.

adsorbed. In order to calculate the value of the intraparticle diffusivity by using equation 2, the amount adsorbed must be measured at regular intervals and at a fixed concentration. In this case, the amount adsorbed at an elapsed time was measured at a fixed concentration of $100 \mathrm{ppm}$ and the equilibrium amount adsorbed was obtained from the adsorption isotherm at an equilibrium concentration of $100 \mathrm{ppm}$.

Figure 3 shows the change in intraparticle diffusivity with the adsorption ratio. The curves of the logarithm of $\mathrm{Di}^{\prime}$ against $\mathrm{F}$ became concave toward $\mathrm{F}$. The intraparticle diffusivity onto surface-modified activated carbon was greater than that onto $\mathrm{AC}$ at each adsorption ratio, and it was particularly marked in PT-AC. In the early stage of adsorption ( $\mathrm{F}$ less than 0.2 ), the intraparticle diffusivity onto the pores of PT-AC and NC-AC was greater than that of AC by as much as 1.7 and 1.5 times for phenol and 3.4 and 1.8 times for cresol, respectively.

According to the study of Masamune and Smith ${ }^{17)}$, the intraparticle diffusivity is equal to the sum of the pore diffusivity and the surface diffusivity. Knoublauch, et al. ${ }^{18)}$ assumed that in the early stage of adsorption, pore diffusion is dominant and that there is a later shift to surface diffusion dominance. Yagi, et al. ${ }^{19)}$ reported that for the adsorption of organic solvents on silica gel, the intraparticle diffusivity is small for small adsorbent mean pore radii. Urano and Kiyoura ${ }^{20)}$ assumed that the intraparticle diffusivity of phenol onto coal was dominated by surface diffusion, because the pore radius of coal was small. Therefore, the intraparticle diffusivity is closely related to the pore structure of the adsorbent. The report of Yagi, et al. ${ }^{19)}$ and our results for PT-AC support the view that the value of intraparticle diffusivity becomes larger with large in transitional pore $(15-16<\mathrm{r}<1000-2000 \AA)$ volume of adsorbent. The fact that the transitional pore volume of NC-AC was small and the intraparticle diffusivity was greater as compared with $\mathrm{AC}$ could be explained by the interaction between the adsorbate and the surface charge of the adsorbent, in a manner similar to the case for the equilibrium amount adsorbed.

The treatment of effluent from hospitals is difficult because of the variety in the types of pollutants. In the activated sludge method, the constituents of disinfectant which is excreted in quantity have been decomposed by acclimating aerobic microorganisms ${ }^{3 \sim 5)}$. However, trace amounts of undecomposed phenols react with chlorine in water and produce chlorophenols, a malodorous substance. Therefore, advanced treatment of the effluent is desirable.

In this investigation, we prepared surface-modified activated carbons and found that NC-AC was 
suitable for the adsorption removal of phenols in effluent from hospitals.

\section{SUMMARY}

The adsorption properties of surface-modified activated carbon for the treatment of the effluent from hospitals were investigated.

The relationship between the amounts of phenol and cresol adsorbed and the pore structure of the adsorbent was not significant. However, the difference in the amount adsorbed could be explained from the interaction between the surface charge of the activated carbon and phenolic anions.

The intraparticle diffusivity of phenol and cresol onto surface-modified activated carbon was greater than that onto AC for each adsorption ratio. For NC-AC and PT-AC, our experiments indicate that the large values for the intraparticle diffusivity are due to the interaction between the surface charges of the adsorbent and adsorbate, and the increase in the transitional pore volume, respectively.

lt is found that NC-AC is suitable for the treatment of effluent from hospitals.

\section{REFERENCES}

1) Hayashi, T.: Water pollution control in Japan, J. Water Poll. Control Fed., 52, 850-861 (1980).

2) Shimura, N.: Waste water regulation in hospitals, Yosui to Haisui, 21, 747-752 (1979). (in Japanese)

3) Sayama, N.: Basic experimental studies on the treatment of cresol, phenol and formalin, Jpn. J. Hyg., 34, 733-742 (1980). (in Japanese)

4) Sayama, N. : Treatment of cresol with a trickling tower plant, Jpn. J. Hyg., 35, 670-675 (1980). (in Japanese)

5) Sayama, N.: Treatment of benzalkonium chloride and chlorhexidine, Jpn. J. Hyg., 35, 869-873 (1981). (in Japanese)

6) Sayama, N. : Identification of bacteria which degrade disinfectants, Jpn. J. Hyg., 36, 560-565 (1981). (in Japanese)

7) Urano, K.: Waste water treatment by activated carbon, Yuki Gosei Kagaku Kyoukaishi, 33, 333-341 (1975). (in Japanese)

8) Sano, H.: Studies on removal of sulfur oxides from flue gas, Report of the Government Industrial Research Institute, Osaka, No. 352, 54-78 (1977). (in Japanese)

9) Urano, K. and Nakai, T.: Intraparticle diffusivities in liquid phase adsorption under nonliner equilibrium, Nippon Kagaku Kaishi, 1486-1491 (1976). (in Japanese)

10) Boki, K. : Studies on the adsorption removal of hydrogen sulfide gas-static and dynamic adsorption characteristics of hydrogen sulfide in gaseous phase on porous activated carbons and zeolites, Jpn. J. Hyg., 32, 482-493 (1977). (in Japanese)

11) Boehm, H.P., Diehl, E., Heck, W. and Sappok, R. : Surface oxides of carbon, Angew. Chem. Internat. Edit., 3, 669-677 (1964).

12) Hassler, J.W. : In “Activated Carbon”, p. 356, Chemical Publishing Company, New York. (1963).

13) Kawazoe, K., Suzuki, Y. and Sugiyama, I. : Removal of organic contaminants from Waste water by activated carbon, Seisan Kenkyu, 27, 104-107 (1975). (in Japanese)

14) Sugiyama, M., Esumi, K., Meguro, K. and Honda, H. : Surface treatment of meso-carbon microbeads by oxygen plasma, Bull. Chem. Soc. Jpn., 58, 2638-2640 (1985).

15) Esumi, K., Sugiura, M., Mori T., Megro, K. and Honda, H.: Surface treatment of bulk meso-carbon by oxidizing and non-oxidizing gas plasma, Tanso, No. 125, 57-61 (1986).

16) Keii, T.: In "Kyuchaku (Adsorption)", p. 158, Kyoritsu Publishing Company, Tokyo. (1970). (in Japanese)

17) Masamune, S. and Smith, J.M. : Adsorption rate studies-significance of pore diffusion, A.I.Ch.E. J., 10, 246-252 (1964).

18) Knoublauch, K., Juentgen, H. and Peters, W. : Kinetic measurements in a differential reactor at constant external concentration, Chem. Ing. Tech., 41, 798-805 (1969).

19) Yagi, T., Shimizu, K., Uchimoto, K. and Maeda, S. : Adsorption kinetics of various hydrocarbons on 
silica gels, Kogyo Kagaku Zasshi, 68, 335-338 (1965). (in Japanese)

20) Urano, K. and Kiyoura, R.: Adsorption characteristics of the coals in aqueous solutions, Kogyo Kagaku Zasshi, 73, 1921-1927 (1970). (in Japanese)

\title{
病院からの廃水処理を指向した表面改質活性炭による
}

\section{フェノールおよびクレゾールの吸着除去}

\author{
徳島大学医学部公衆衛生学教室 \\ 中 村 武夫 夫三 好保・棚 田成 紀・坊 木 佳人
}

病院からの廃水処理を指向して, 表面改質活性炭（含窒素活性炭, 低温酸素プラズマ照射処理活性炭）を調整し, 消 毒薬成分であるフェノールおよびクレゾールの吸着除去実験を試みた。

活性炭に対するフェノールおよびクレゾール吸着量と吸着剂の細孔構造との間には有意な相関関係は認められなかっ た。吸着量の差は, 活性炭表面の荷電状態と吸着質のフェノール性アニオンとの相互作用に起因することが示唆された。 吸着速度に関して, 表面改質活性炭へのフェノールおよびクレゾールの粒内拡散係数は, 各吸着率において, 原活性 炭に対するよりも大きな值を示した。含窒素活性炭およびプラズマ照射処理活性炭において大きな粒内拡散係数を示し た理由は，それぞれ吸着質であるフェノールおよびクレゾールと吸着剂表面の荷電状態との相互作用，プラズマ照射処 理による活性炭のトランジショナル孔容積が増大したことに基づくものであると考えられる。

病院からの廃水を処理する際, 含窒素活性炭が至適であることが判明した。

Key words: Effluent from hospitals, Surface-modified activated carbon, Equilibrium amount adsorbed, Intraparticle diffusivity 病院廃水, 表面改質活性炭, 平衡吸着量, 粒内拡散係数 